\title{
Measuring The Costs Of Protection In Venezuela
}

Hugo J. Faría, (E-mail: hugofaria@supercable.net.ve), Instituto de Estudios Superiores de Administración, Venezuela Jorge González, (E-mail: distumiven@hotmail.com), Distumiven, Venezuela

Luis Penzini, (E-mail: lpenzini@cantv.net), Centro Nacional de Telecomunicaciones, Venezuela

Ricardo Pérez, (E-mail: rperez@corpbanca.com.ve), American Express, Venezuela Stephanie Zalzman, (E-mail: szalzman@consein.com), Cosein, Venezuela

Jesús Zerpa, (E-mail: jesus.zerpa@intl.fritolay.com), Los Cortijos de Lourdes, Venezuela

\begin{abstract}
This research looks into the static effects on the Venezuelan economy of removing trade barriers in the form of tariffs in textiles, agricultural products, steel and automobile. Based on a methodology used by the United States International Trade Commission, this paper documents that gains to consumers for every job lost range from $\$ 85,384$ in the agricultural industry to $\$ 1,096,714$ in the automobile industry. Removal of these barriers would increase national welfare in excess of $\$ 1$ billion per year, which is equivalent to 1\% of Venezuela's GDP (based on statistics from the 90's). This evidence suggests significant misallocation of resources that may retard the growth process.
\end{abstract}

\section{INTRODUCTION}

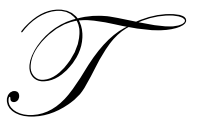

he current wave of globalization is characterized by some developing countries reducing trade barriers, removing capital controls, and improving their economic environment by virtue of market reforms. According to Dollar and Kraay (2001) there were more open emerging economies during the 90's, as well as GDP per capita growth rates that exceeded those of rich countries, thereby igniting a process of convergence. This subset of developing countries is home to 3 billion people and includes densely populated countries such as China and India. On the contrary, the countries that have failed to become more globalized and to improve their investment climate ( 2 billion population) suffered negative per capita income growth.

Trade and growth are highly positively correlated. Although the cause and effect relation between trade and growth has not been fully clarified, much evidence suggests that greater trade stimulates higher growth rates. Lindert and Williamson (2001) indicate that: "The doubts that one can retain about each individual study threaten to block our view of the overall forest of evidence. Even though no one study can establish that openness to trade has unambiguously helped the representative Third World economy, the preponderance of the evidence supports this conclusion" (pp. 29-30). For evidence on growth induced by trade see Ades and Glaeser (1999) and Frankel and Romer (1999).

Moreover, Parente and Prescott (2000) emphasize the importance of competition, which may be induced by trade, as a catalyst for growth. According to their view, the stock of usable knowledge has increased substantially since the Industrial Revolution, and when countries break monopoly barriers (that stifle the adoption of more efficient methods of production), they experience high growth rates. Moreover, the longer it takes the economy to break the barriers that prevent it from accessing the expanded stock of accumulated knowledge, the greater the growth rates initially endured. In general, countries achieving an annual income mark of \$2,000 before 1950 took a median length of 45 years to double their income per capita level. In contrast, countries achieving $\$ 2,000$ annual income after 1950 were able to double their income in a median length of 15 years.

Not surprisingly, to preclude the protection of vested interests to a particular production process, Parente and Prescott advocate free trade and the concomitant greater competition. "To promote competition, governments should 
foster free trade. The state needs to ensure that goods and services can move freely between regions inside its country's borders and between countries. International trade, thus, matters for development precisely because it is an important source of competition" [Parente and Prescott (2000) page 143]

Finally, consistent with the hypothesis of growth induced by trade, the high growth rates endured by the more globalized developing economies indicate a cessation of people falling into poverty and has actually reduced the number of poor people. Accordingly, the number of people living on less than a dollar a day has fallen by approximately 200 million. [Bourguignon and Morrison (2001) and Chen and Ravallion (2001)]

In stark contrast to this scenario of an increasingly more affluent world, the modern economic growth literature has characterized the Venezuelan economy as a growth disaster, Barro and Sala-i-Martin (2004) and Jones (2002). Between 1960 and 2000 the Venezuelan economy suffered negative real per capita income growth of $0.2 \%$. In the year 1960, Venezuela's income per capita was equivalent to $83 \%$ of U.S. income. In the year 2000, Venezuela's income per capita had declined to $46 \%$ of the U.S. Thus, the Venezuelan economy has been swimming against the overall world current. On average, the world has become more affluent, while the Venezuelan economy has become increasingly impoverished. The absence of prosperity and declining living standards during the last 40 years explains the current Venezuelan political and social crises.

The causes of income stagnation are varied, and there are no simple answers. Nonetheless, absences of the following institutions are notorious in the Venezuelan economy.

- $\quad$ First, Rule of Law and protection of property rights.

- $\quad$ Second, a simplified and non-confiscatory tax code.

- $\quad$ Third, a privately based ownership structure of the country. This new ownership composition should be extended to major corporations, assets and even the subsoil.

- $\quad$ Fourth, small government: efficiently providing a legal infrastructure and facilitating investment in human capital in the form of education and health.

- $\quad$ Fifth, price stability: that is, low inflation to minimize the inflation tax.

- $\quad$ Finally, low trade barriers to prevent Venezuela's ubiquitous inefficient industries whose presence suggests significant levels of rent-seeking activity.

This paper attempts to shed light on the Venezuelan stagnation conundrum by examining the cost consequences of not becoming a more globalized economy. Specifically, focusing on the curtailment of trade flows due to high trade barriers, (tariffs alone average 15\%), this research project attempts to measure the welfare costs associated with the presence of tariffs in the most egregious industry cases of protection. High tariffs unnecessarily increase the cost of living to average citizens, therefore contributing to their impoverishment.

In the Venezuelan case, increased competition brought about by freer trade would contribute to break the cycle of stymied competitive forces induced by Venezuelan governmental policies. In other words, not only does the Venezuelan government not adequately promote competition among local producers; but also, the Venezuelan government is founder of the OPEC oil cartel. Hence, the Venezuelan government actively colludes with other oil producers to fix prices. Consequently, the government, in addition to creating an anti-competitive environment, has no moral authority to preclude monopolist practices.

The scope of this research is to estimate the static welfare benefits emanating from eliminating tariff trade barriers in some of the most conspicuously protected industries in Venezuela. The industries this paper examines are agriculture, textiles and apparel, automobile, and steel. The specific agricultural products studied are corn, rice, wheat, sugar, sorghum and milk. In steel, items investigated are flat products (hot roll, cold roll and coated), non-flat products (re-bars, bars, wire rod, light bearings, angles and wire mesh), semi-finished products (slabs and billets) and tubular products.

Considering that this investigation only measures static welfare costs, it understates the benefits to society from the adoption of unrestricted trade policies. Specifically, there is no attempt to measure the dynamic efficiency 
gains in the form of a more efficient allocation of resources engendered by a more competitive environment. In addition, this investigation does not account for welfare costs associated with non-tariff barriers such as sanitary permits, packaging, labeling, exchange controls and poor functioning of customs. Another limitation of this paper is that it relies on a partial equilibrium model contributing o impart a downward bias to welfare cost estimates. Additionally, this paper does not assess inefficiencies induced by rent-seeking activity (which tends to sprawl in the presence of trade barriers and substantial government officials' discretionary powers).

The major findings suggest the existence of significant costs to Venezuelan consumers due to high tariffs. Most probable case scenarios indicate that by eliminating tariffs, the gains to consumers per job lost (annual avg.) in textiles and apparel mount to $\$ 89,001$. For agricultural products, the gains to consumers per job lost are of $\$ 85,384$. Finally, in the steel industry and automobiles the magnitudes of gains to consumers per job lost are $\$ 144,617$ and $\$ 1,096,714$ respectively. To put these results in perspective consider that most workers in Venezuela are paid minimum wages. Adding other potential benefits derived from contractual labor agreements, these workers could earn an average of $\$ 3,000$ annually.

The rest of the paper is organized as follows: The second section discusses the methodology employed and indicates data sources. The third section contains the major findings and the last section concludes the paper and includes policy recommendations.

\section{METHODOLOGY}

\section{Data Sources}

Employment: Oficina Central de Estadística e Informática, (OCEI) a governmental agency was the employment source for textiles, apparel and steel. OCEI offers accurate estimates of the number of people employed in the aforementioned industries. For agricultural products, estimates had to be made from data on a 1997 census provided by the Venezuelan Department of Agriculture and Commerce.

Imports: The data was provided by OCEI. The institute records physical volume and Cif amounts in local currency and dollars for all imports.

Domestic Production and Capacity Utilization: For agricultural products, data was obtained from the Venezuelan Department of Production and Commerce and "Panorama de la Agricultura de America Latina y el Caribe", this is a study performed by Cepal. For textile and steel products, estimates were obtained from private associations (chambers) of steel and textiles producers.

Tariff: From official governmental publications containing nominal tariff barriers on imports. Figure A1 shows average tariffs during the nineties in Venezuela.

Elasticity estimates: Were obtained from prior studies conducted on developed and developing economies plus recent working papers. A full citation of these studies is contained in the reference section.

\section{Empirical Methods}

The methodology employed in this research computes a partial equilibrium model that simulates scenarios in which protection is eliminated. This methodological procedure also facilitates international comparisons among the countries that have been subject to this type of study. Hufbauer and Elliot (1994) the United States; Sazanami, Urata and Kawai (1995) Japan; Kim (1996) South Korea; Shuguang, Yansheng and Zhongxin (1998) China; and Messerlin (2001) Europe. This section draws substantially from these prior studies. 
The model is based on four key assumptions:

- $\quad$ The domestic good and the imported good are imperfect substitutes.

- $\quad$ The supply schedule for the imported good is flat (perfectly elastic).

- $\quad$ The supply schedule for the domestic good is upwardly sloped (less than perfectly elastic).

- $\quad$ All markets are perfectly competitive.

The static effects of removing a trade barrier (either a tariff or a quota) are illustrated in Figures 2.1 and 2.2. For example, elimination of a tariff lowers the price of the import in the domestic market from Pm to Pm' in Figure 2.1. In Figure 2.2, the decrease in the price of the imported good causes an inward shift in the demand curve for the domestic commodity from Dd to Dd'. This in turn leads to a decrease in the price of the domestic product from Pd to Pd'.

Figure 2.1: Effects in the import market of removing a trade barrier

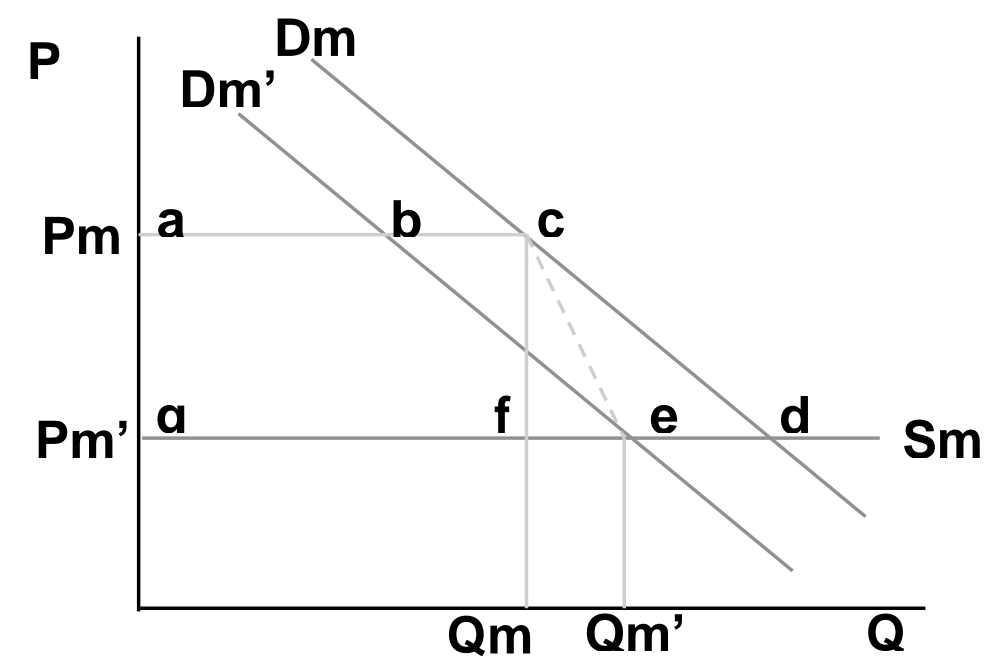

Figure 2.2: Effects in the domestic market of removing a trade barrier

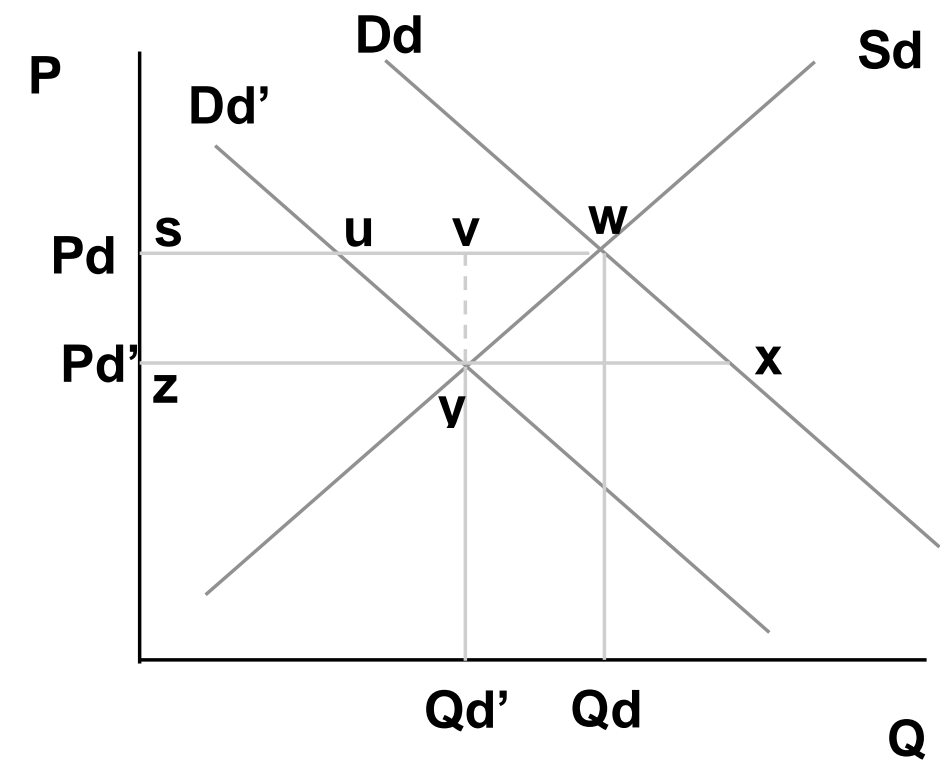


Returning to Figure 2.1, the decrease in the domestic price causes the demand schedule for the imported good to shift from Dm to Dm'. When equilibrium is restored, prices of both the imported good and the domestic good are lower. Output of the domestically produced good is also lower (by the difference between Qd and Qd'), and the quantity of imports is higher (by the difference between Qm and Qm').

\section{Calculating The Welfare Effects Of Trade Barriers}

The changes in prices and quantities due to trade liberalization result in a gain of consumer surplus, both in the import market and the domestic market. Part of the gain arises because consumers now pay less for a good than they paid when supply was restricted. In addition, some consumers (who previously were priced out of the market entirely) will now enter the market. The consumer surplus gain due to liberalization, however, is partially offset by a loss in producer surplus in the market for the domestic substitute, where prices and output both fall.

If the trade restraint took the form of a tariff, then the revenue lost by the government would also partially offset the consumer gain. If instead a quantitative restraint $(\mathrm{QR})$ was used, liberalization would eliminate the quota rents that previously went either to domestic importers or foreign exporters, or some combination of the two, depending both on how the QR was allocated and on the economic power of the market participants (see Bergsten et al. 1987). Finally, there will be an efficiency gain because the trade restraint results in a misallocation of resources. Before liberalization, the wedge created between the domestic price of the import and the world price caused a transfer of resources toward production of the import substitute and away from other sectors where those resources could have been used more efficiently.

The methodology used to quantify these welfare effects is based on Morke and Tarr (1980). Because the imported and domestic goods are imperfect substitutes, the total gain to consumers must be calculated as the sum of the consumer surplus gain in the two separate markets. Referring to Figure 2.1, Morke and Tarr estimate that the consumer surplus gain from liberalization in the import market is approximated by the area bounded by points aceg. This method of estimating the consumer gain in the import market follows from the analysis of Burns (1973) on the measurement of consumer surplus and gives an average of the consumer gains calculated separately from the two demand curves. Using the old demand schedule, $(\mathrm{Dm})$ the area marked acdg as the change in consumer surplus, while the new demand schedule (Dm') gives the area marked bcde. Line ce divides the area in half and gives the compromise consumer surplus change, area aceg. Area aceg can be estimated by adding rectangle acfg to triangle cef.

If the form of the protection is a tariff, the rectangular area acfg represents a transfer from the government to consumers in the form of lost tariff revenues, and may be estimated as:

$$
T R L=\left(P_{m}-P_{m}^{\prime}\right) \times Q_{m}
$$

The area of the triangle marked cef represents recovery of the deadweight efficiency loss, which may be estimated as:

$$
R D E L=\frac{1}{2} \times\left(P_{m}-P_{m}^{\prime}\right) \times\left(Q_{m}^{\prime}-Q_{m}\right)
$$

If quantitative restraints are used, and if all previous quota rents have been captured by foreign exporters, then area acfg is recovered by the domestic economy from foreign interests. In that case, the consumer gain in the import market (the sum of rectangle acfg and triangle cef) will also equal the national welfare gain. If both tariffs and quotas are imposed, the tariff equivalent of the quota is assumed to be the difference between the total decline in the import price $(\mathrm{Pm}-\mathrm{Pm}$ ') and the price effect of the tariff.

Turning next to the domestic effects in Figure 2.2, the consumer welfare gain from lower domestic prices may be approximated by the area marked swyz. Area swyz can be estimated by adding rectangle svyz and triangle vwy. This amounts to: 


$$
P S L=\left(P_{d}-P_{d}^{\prime}\right) \times Q_{d}^{\prime}+\frac{1}{2} \times\left(P_{d}-P_{d}^{\prime}\right) \times\left(Q_{d}-Q_{d}^{\prime}\right)
$$

In the domestic market, the consumer surplus gain is just offset by the producer surplus loss.

\section{Model Implementation}

In order to derive solutions for individual industries, a computable partial equilibrium model corresponding to Figures 2.1 and 2.2 was devised. The model assumes that supply and demand relationships are not linear in their absolute terms, but rather that they are linear in their logarithmic terms. This assumption enables the parameters associated with the price terms to be interpreted as elasticities.

The underlying domestic supply and demand functions are specified according to the equations:

$$
Q_{d}=a P_{d}^{E d d} P_{m}^{E d m}
$$

and

$$
Q_{s}=b P_{d}^{E s}
$$

In equation 2.4, Edd is the own-price elasticity of demand for the domestic good, while Edm is the cross-price elasticity of demand for the domestic good with respect to the price of the imported good. In equation 2.5, Es is the own-price elasticity of supply of the domestic good. Because the domestic good and the imported good are imperfect substitutes in this model, equilibrium in the domestic market requires that domestic demand equal domestic supply (i.e., Qd = Qs).

Assuming that the supply of the import is perfectly elastic, the demand and supply equations in the import market are:

$$
Q_{m}=c P_{d}^{E m d} P_{m}^{E m m}
$$

and

$$
P_{m}=P_{m}^{\prime \prime}(1+t)
$$

In equation 2.6, Emd is the cross-price elasticity of demand for the imported commodity with respect to the price of the domestic commodity, while Emm is the own-price elasticity of demand for the imported commodity. Equation 2.7 represents the assumption that the supply of the imported commodity is perfectly elastic, and that the world market CIF price, Pm', is therefore the same regardless of import quantity.

This system of supply and demand functions may be converted into a system of linear relationships by taking logarithms to the base $e$ of equations 2.4 through 2.7:

$\ln Q_{d}=\ln a+E_{d d} \ln P_{d}+E_{d m} \ln P_{m}$

$\ln Q_{s}=\ln b+E_{s} \ln P_{d}$ 


$$
\begin{aligned}
& \ln Q_{m}=\ln c+E_{m d} \ln P_{d}+E_{m m} \ln P_{m} \\
& \ln P_{m}=\ln \left[P_{m}^{\prime \prime}(1+t)\right]
\end{aligned}
$$

In the Venezuelan agricultural sector, importers face a price band that moves in opposite direction to the international price of commodities. The goal of the price band is to maintain constant prices of imported goods at a level that insulates domestic producers from foreign competition.

Equations 2.8 through 2.11 are used to calculate the welfare effects of liberalization. The calculation involves six basic steps: first, equations 2.8 through 2.11 require estimation of the elasticity parameters and data on quantity and prices. Second, solve the system of equations to estimate the unobservable parameters, lna, lnb and lnc. Third, compute the new international price $1 \mathrm{nPm}$ ' after tariff elimination. Fourth, invoking the equilibrium condition $\ln _{\mathrm{d}}=$ $\ln Q_{s}$, find the post-liberalization domestic price as a function of the new import price. Fifth, substitute the new prices in equations 2.8 through 2.11 to yield the new domestic equilibrium quantities of imports and domestic output. Finally, the welfare effects of tariff changes are calculated using equations 2.1,2.2 and 2.3. These calculations will allow the derivation of realistic conclusions on Venezuela's trade system efficiency and liberalization impacts. (See below for estimation of elasticities parameters.)

For example, analysis of a scenario in which tariff protection is eliminated will yield Equation 2.13 with the domestic price as a function of the import price:

$\ln P_{d}^{\prime}=\frac{(\ln a-\ln b)}{E_{s}-E_{d d}}+\frac{E_{d m}}{E_{s}-E_{d d}} \ln P_{m}^{\prime}$

Substituting the world price as the new import price in equation 2.10 gives the new domestic price. Having calculated the new prices in the post-liberalized economy, equations 2.8 and 2.11 furnish the new quantities for

domestic production and imports. Finally, substituting the new quantities and prices in equations 2.1, 2.2 and 2.3 will provide an estimate of the welfare effects associated with the trade liberalization policy.

The case where a quota is eliminated is more complex. If the new quantity of imports (Qm') can be estimated, then from equation 2.10, $1 \mathrm{nPm}$ ' can be solved as a function of $1 \mathrm{nQm}$ ' (the new quantity of imports after removing the quota) and lnPd'. This is illustrated in equation 2.14 below:

$\ln P_{m}^{\prime}=\frac{\left(\ln Q_{m}^{\prime}-\ln c-E_{m d} \ln P_{d}^{\prime}\right)}{E_{m m}}$

Solving equations 2.13 and 2.14 simultaneously will yield the two new prices: $\ln P m$ ' and $\operatorname{lnPd}$ '. These, in turn yield the output of the domestic commodity using equation 2.8. Once again, the comparative-static welfare effects of the change in protection may be estimated using the formulation described in equations 2.1, 2.2 and 2.3.

\section{Computing Elasticities of Demand and Supply}

Values for some of the elasticity parameters needed for the model are not available in the referenced literature. Estimates of cross-price elasticities, in particular, are rare. As outlined below, assumptions about the relationships among the parameters have been made as necessary to estimate unknown parameters based on the values that are available.

In some cases, an estimate of the price elasticity of aggregate demand for imports and the domestic good combined is available, while separate estimates for the two own-price elasticities of demand are not known. In order 
to facilitate computation, it is assumed that the demand structure is of the "constant elasticity of substitution" (CES) form. If the elasticity of substitution between the two commodities is available, or can be estimated, estimates of the own-price- elasticities of demand may be derived using the following equations:

$$
\begin{aligned}
& E_{d d}=-\left[\left(1-S_{d}\right) \times \sigma+\left(S_{d} \times E_{d t}\right)\right] \\
& E_{m m}=-\left[\left(1-S_{m}\right) \times \sigma+\left(S_{m} \times E_{d t}\right)\right]
\end{aligned}
$$

where, $E d t=$ price elasticity of total demand, $s=$ elasticity of substitution between the domestic and imported goods (with both defined to be positive), $S d$ is the share by value of the domestic product in consumption, and $S m$ is the share by value of imports in consumption (see Tarr 1990, 262, equation 16).

Following a methodology developed by David Tarr (1990, 262, equation 17), if these own-price elasticities of demand and the elasticity of aggregate demand are known, the cross price elasticities in the CES case may be calculated from:

$$
\begin{aligned}
& E_{m d}=-\frac{\left[S_{d}\left(E_{d t} \times E_{d d}\right)\right]}{S_{m}} \\
& E_{d m}=-\frac{\left[S_{m}\left(E_{d t} \times E_{m m}\right)\right]}{S_{d}}
\end{aligned}
$$

An alternative methodology has been developed by Rouslang and Suomela $(1985,85)$. In many cases, the elasticity of aggregate demand is not available, but estimates of one or both of the own-price elasticities of demand are available in the literature. Using the Rousslang-Suomela method, the cross-price elasticities may be derived as follows:

$$
\begin{aligned}
& E_{m d}=\frac{V_{d}}{V_{m}-V_{d}}\left(E_{m m}-E_{d d}\right) \\
& E_{d m}=\frac{V_{m}}{V_{d}-V_{m}}\left(E_{d d}-E_{m m}\right)
\end{aligned}
$$

where, $\mathrm{Vd}$ is the value of domestic production, and $\mathrm{Vm}$ is the value of imports, c.i.f., duty-paid. These approximations assume there is little difference between the measured own-price elasticities of demand and the underlying compensated own-price elasticities, which would reflect the responsiveness of demand changes to relative price changes if consumers were compensated (or taxed) to offset the change in real incomes that result from the price change itself (Rousslang and Parker 1984) and (Rousslang and Suomela 1985).

Finally, in many cases, the elasticity of supply also is not known. If a plausible value for the coefficient of price response $\left(\mathrm{Pd}-\mathrm{Pd}^{\prime}\right) /\left(\mathrm{Pm}-\mathrm{Pm}^{\prime}\right)$ can be determined, then the elasticity of supply for the domestic good may be estimated by:

$$
E_{s}=\frac{E_{d d}-E_{d m}}{\theta}
$$


where, $\theta$ is the coefficient of price response (Cline 1990, 362, equation 19).

\section{Compas Modeling}

The calculations of the mathematical model described previously were accomplished using two different programs: the Compas Files and an MS Excel spreadsheet based on Hufbauer and Elliot (1994). Compas is a standard computational tool developed by Joseph Francois and Keith Hall and is frequently used by the United States International Trade Commission (USITC).

\section{RESULTS}

Table 3.1:

Gain to Consumers per Job Lost.

Best Adjusted Case for the Venezuelan Market during the 90's. Values correspond to annual averages.

\begin{tabular}{|c|c|c|c|c|}
\hline Id & Industry / Product & $\begin{array}{c}\text { Total Cost to } \\
\text { Consumers } \\
\text { (US\$) }\end{array}$ & $\begin{array}{l}\text { Employment } \\
\text { Lost: }\end{array}$ & $\begin{array}{c}\text { Gain to } \\
\text { Consumers per } \\
\text { Job Lost (US\$) }\end{array}$ \\
\hline & TEXTILES & 104.991 .589 & -1.180 & $\mathbf{8 9 . 0 0 1}$ \\
\hline $\mathbf{1}$ & Textiles & 52.503 .535 & -603 & 87.116 \\
\hline$\overline{2}$ & Apparel & 52.488 .054 & -577 & 90.970 \\
\hline & AGRICULTURAL & 369.548.314 & -4.328 & 85.384 \\
\hline 3 & Manufactured Milk (Dairy Products) & 122.246 .419 & -1.512 & 80.847 \\
\hline 4 & Corn & 151.204 .519 & -1.758 & 86.015 \\
\hline 5 & Rice & 6.364 .739 & -67 & 94.314 \\
\hline 6 & Sorghum & 2.465 .802 & -43 & 56.814 \\
\hline 7 & Wheat & 41.188 .989 & & \\
\hline 8 & Sugar & 46.077 .847 & -947 & 48.644 \\
\hline & STEEL & 68.351 .565 & -473 & 144.617 \\
\hline 9 & Flat Products (Hot roll,Cold roll,Coated) & 25.181 .305 & -150 & 168.021 \\
\hline 10 & $\begin{array}{l}\text { Noflat Products (Rebars,Bars, Wire rod,Light } \\
\text { Bearris,Angles, Wire mesh) }\end{array}$ & 12.795 .718 & -83 & 155.049 \\
\hline 11 & Semi finished Products (Slabs,Billets) & 506.761 & -150 & 3.379 \\
\hline $\mathbf{1 2}$ & Tubular & 29.867 .781 & -90 & 330.855 \\
\hline & AUTOMOBILES & 494.618 .000 & -451 & 1.096 .714 \\
\hline 13 & Automobiles & 494.618 .000 & -451 & 1.096 .714 \\
\hline & TOTAL & 1.037 .509 .468 & -6.431 & 161.319 \\
\hline
\end{tabular}

Results contained on Table 3.1 suggest the presence of substantial costs to consumers due to the presence of trade barriers in the form of tariffs. Most workers examined in the Venezuelan industries earn less than $\$ 5,000$ annually. Considering that gains to consumers per job lost due to liberalization averages $\$ 161,319$, the benefits are large enough to compensate workers who lose their jobs. These results indicate the handiness of implementing trade adjustment mechanisms aimed at minimizing hardships associated with job losses due to free trade. In addition, the existence of compensating mechanisms would contribute to alleviate resistance to the adoption of free trade policies.

Documented welfare losses also suggest the presence of substantial misallocation of resources, which tend to retard growth of GDP. This perception is supported by additional information, contained in the Appendix, from the agricultural products investigated. Figure A2 shows that Venezuela's productivity in corn, rice and sorghum is substantially lower than in other parts of the world, including Latin America. In corn, specifically, Venezuela's productivity (measured in kilograms per hectare) is less than a third of Latin America's most productive country, and is slightly above one tenth of the best of the world. In rice and sorghum, Venezuela's productivity lags substantially behind the best of Latin America and is less than half of the world's best. In milk, Venezuela's productivity is less than two thirds of the best in Latin America and slightly above one fifth of the best of the world. 
Productivity in the agricultural products studied is not only low compared to other countries, but is basically without trend. Figure A3 shows stagnant productivity during the nineties for corn, rice, and sorghum. Moreover, Figure A4 contains substantial differences between domestic and international prices. Internal prices paid by producers, users of these inputs, are $73 \%$ to $118 \%$ higher than international prices. Higher input price lessens competitiveness of manufacturing companies and induces increased prices to consumers. Figure A5 indicates that Venezuela's per capita trade is low compared to other Latin American countries and the world average. This outcome is partly the consequence of ill-conceived policies of food security, which in essence promotes isolationist policies under the banner of reducing food dependency.

Finally, this paper underestimates benefits from free trade because dynamic efficiencies stemming from the elimination of trade barriers are not measured. In other words, trade liberalization causes less efficient firms to perish; and freed resources are allocated to higher valued uses, increasing society's welfare and possibly creating more stable jobs.

\section{CONCLUSIONS}

Over the last 40 years, the world has increasingly become more globalized and wealthy. At the root of less world poverty is an acceleration of the growth rate of real income per capita. Evidence suggests that higher volumes of trade account partially for an increased growth rate.

The Venezuelan economy exhibits an anomalous behavior relative to the rest of the world. Over the last 40 years, real per capita income has experienced on average negative growth on a per capita basis of $0.2 \%$. Although causes for this dismal performance are multiple, this paper posits that greater levels of unimpeded trade should contribute to reverse Venezuela's negative growth tendency. Nonetheless, greater opening of the Venezuelan economy should occur gradually and unilaterally after undergoing a process of increased stability.

This paper documents substantial costs to consumers spawned by the presence of trade restrictions. Consumer gain per job lost in various industries range from $\$ 48,644$ (sugar) to $\$ 1,096,714$ (automobile). These results are better ascertained by taking into account that most workers are paid minimum wage in Venezuela and that these wages amount to less than $\$ 5,000$ annual income. This evidence suggests significant misallocation of resources that may retard the growth process.

\section{APPENDIX}

Figure A.1: Average Tariff Per Sector In Venezuela (Years: 1990-1999)

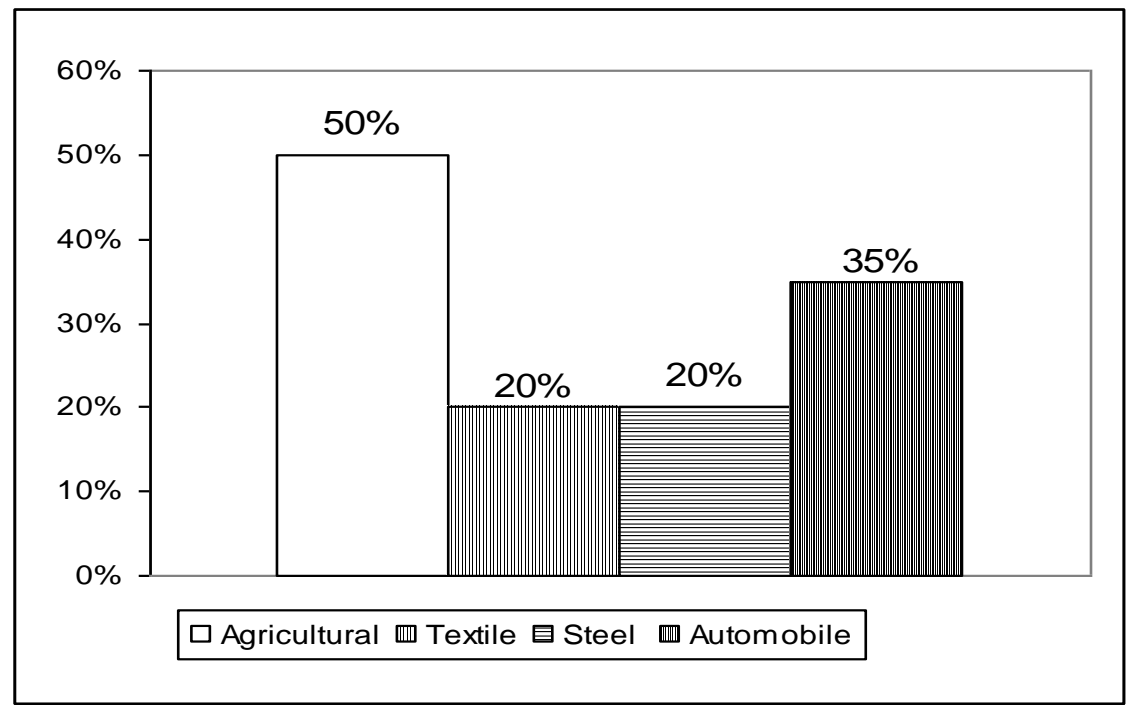


Figure A.2: Productivity Indicators for Agricultural in Venezuela

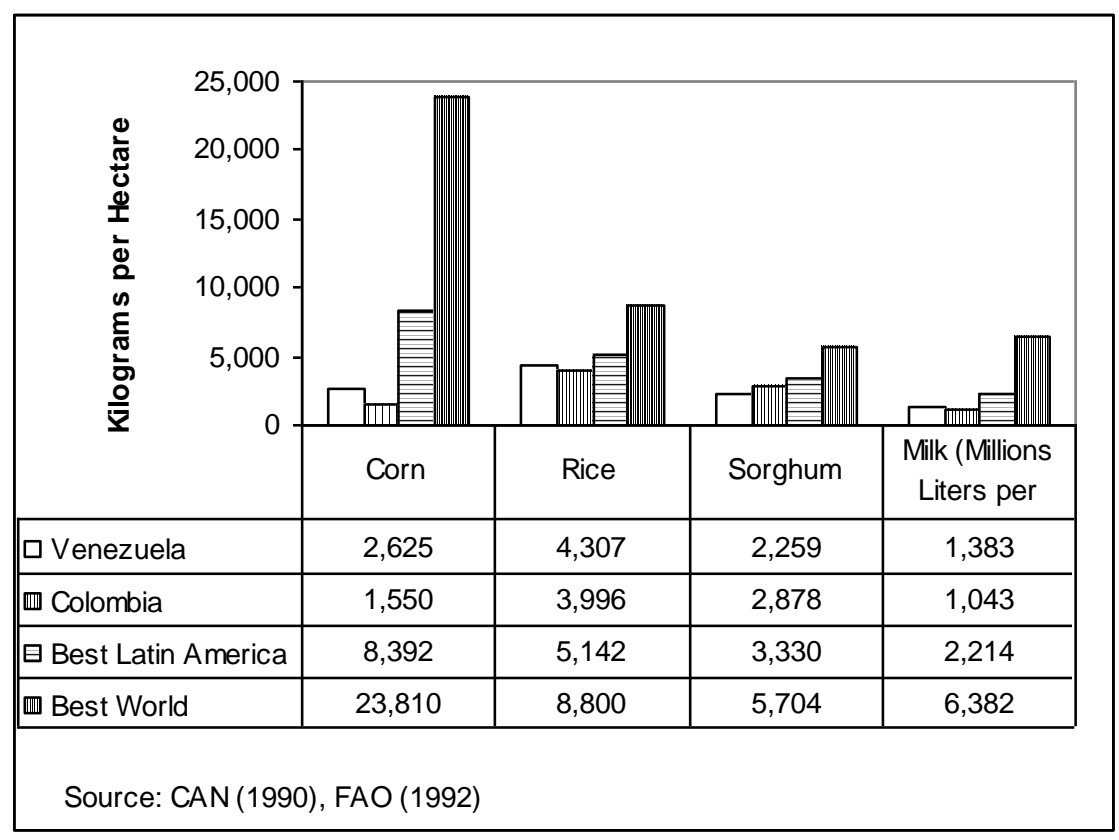

Figure A.3: Productivity per Year of Selected Cereals in Venezuela (1990-1999)

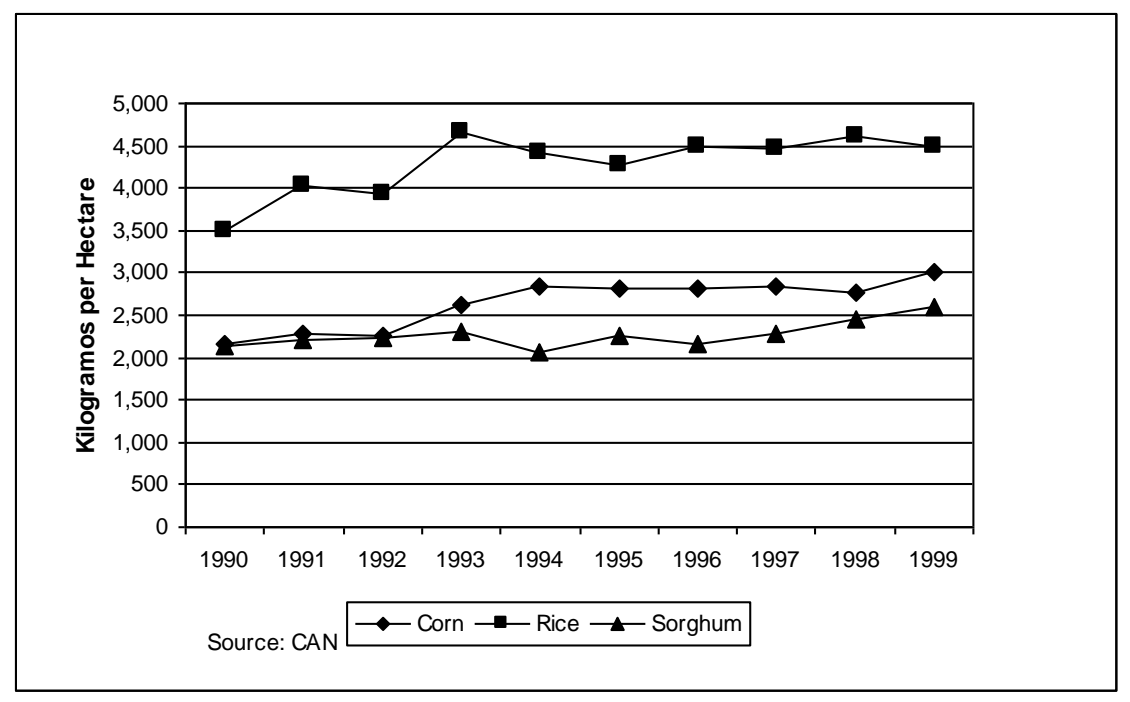


Figure A.4: Prices of Agricultural Products: Domestic vs. International Market

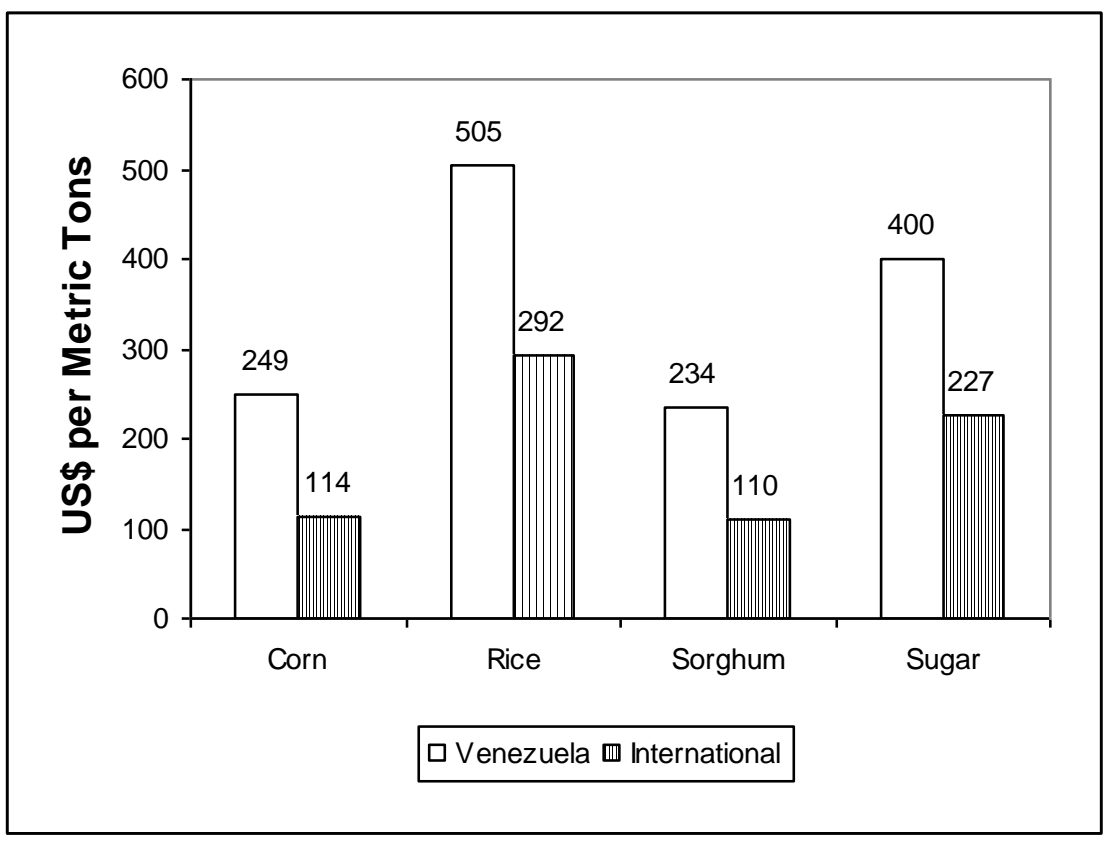

Notes Fig. A.4: (1) Average prices: 1990-1999. (2) Producer prices in Venezuela. (3) International prices: FOB

Table A.5: Agricultural Trade Per-Capita (FAO: 1998)

\section{US\$ per Person}

Holland

Australia

Costa Rica

Argentina

Canada

Ecuador

Brasil

USA

\begin{tabular}{rrr} 
Export & Import & Balance \\
1,928 & 1,121 & $\mathbf{8 0 7}$ \\
775 & 143 & $\mathbf{6 3 2}$ \\
468 & 90 & $\mathbf{3 7 8}$ \\
344 & 46 & $\mathbf{2 9 8}$ \\
504 & 355 & $\mathbf{1 4 9}$ \\
129 & 58 & $\mathbf{7 1}$ \\
92 & 35 & $\mathbf{5 7}$ \\
209 & 153 & $\mathbf{5 6}$ \\
93 & 43 & $\mathbf{5 0}$ \\
48 & 23 & $\mathbf{2 5}$ \\
58 & 51 & $\mathbf{7}$ \\
6 & 4 & $\mathbf{2}$ \\
10 & 11 & $\mathbf{- 1}$ \\
\hline $\mathbf{7 1}$ & $\mathbf{7 7}$ & $-\mathbf{6}$ \\
\hline 4 & 17 & $\mathbf{- 1 3}$ \\
72 & 89 & $\mathbf{- 1 7}$ \\
26 & 59 & $\mathbf{- 3 3}$ \\
\hline 24 & 76 & $\mathbf{- 5 3}$ \\
\hline 12 & 275 & $\mathbf{- 2 6 3}$ \\
113 & 444 & $\mathbf{- 3 3 1}$
\end{tabular}

Colombia

Bolivia

Nicaragua

India

China

WORLD AVERAGE

Nigeria

Mexico

Peru

Venezuela

Japan

Norwegian

113

$-331$ 
We are grateful for helpful comments from Sean Durkin and Helen Levy from the University of Chicago, Christine McDaniel and Walker Pollard from the United States International Trade Commission, Ben Goodrich from the Institute of International Economics, and Carlos Machado from IESA.

\section{REFERENCES}

1. Ades, A., and E. Glaeser. 1999. Evidence on Growth, Increasing Returns, and the Extent of the Market. Quarterly Journal of Economics 114(3).

2. $\quad$ Barro, R., and X. Sala-i-Martin. 2004. Economic Growth Second edition, MIT Press.

3. Bourguignon, F., and C. Morrison. 2001. Inequality among World Citizens: 1820-1992. Working Paper 2001-2025, DELTA, Paris.

4. Burns, M. 1973. A Note on the Concept and Measure of Consumer's Surplus. American Economic Review, 63 PP 335-344.

5. $\quad$ CEPAL 2001. Programa de la Agricultura de America Latina y del Caribe.

6. Chen, S., and M. Ravallion. 2001. How Did the World's Poorest Fare in the 1990s? Development Research Group, World Bank, Washington, D.C.

7. Cline, W. 1990. The Future of World Trade in Textiles and Apparel. Washington, Institute for International Economics.

8. Dollar, D., and A. Kraay. 2001. Trade, Growth and Poverty. Policy Research Working Paper No. 2199, World Bank, Washington, D.C.

9. $\quad$ Frankel, J., and D. Romer.1999. Does Trade Cause Growth? American Economic Review, 89(3).

10. Hufbauer, G. and K. Elliot 1994. Measuring the Costs of Protection in the United States. Institute for International Economics.

11. Jones, C. 2002. Introduction to Economic. Growth Norton.

12. Kim, N. 1996. Measuring the Costs of Visible Protection in Korea. Institute for International Economics.

13. Lindert, P., and J. Williamson. 2001. Globalization: A Long History. Paper prepared for the Annual Bank Conference on Development Economics-Europe conference. World Bank, Europe-Barcelona. June 25-27.

14. Messerlin, P. 2001. Measuring the Costs of Protection in Europe Institute for International Economics.

15. Morke, M. and D. Tarr. 1980. Effects of Restrictions on United States Imports: Five Case Studies and Theory. Bureau of Economics Staff Report. Federal Trade Commission.

16. OCEI 1998. Principales Indicadores de la Industria Manufacturera 1988-1997. Total Nacional por Agrupación Económica: 321 (Textil).

17. Parente, S., and E. Prescott. 2000. International Income Facts. Barriers to Riches. MIT Press.

18. Rouslang, D. and P. Stephen. 1984. Cross-Price Elasticities of U.S. Import Demand. Review of Economics and Statistics, 66.

19. Rouslang, D. and J. Suomela. 1985. Calculating the Consumer and Net Welfare Costs of Import Relief. Staff Research Study 15. U.S. International Trade Commission.

20. Sazanami, Y., S. Urata and H. Kawai. 1995. Measuring the Costs of Protection in Japan. Institute for International Economics.

21. Shuguang, Z., Z. Yansheng and W. Zhongxin.1998. Measuring the Costs of Protection in China. Institute for International Economics.

22. Tarr, D. 1990. A Modified Cournot Aggregation Condition for Obtaining Estimates of Cross-Elasticities of Demand. Eastern Economic Journal 16, pp 257-264. 
International Business \& Economics Research Journal - September 2005

Volume 4, Number 9

NOTES 